\title{
Modeling Rodent Proof House in Pati Regency to Reduce Leptospirosis
}

\author{
Rr. Anggun Paramita Djati ${ }^{1 *}$, Asyhar Tunissea ${ }^{2}$, Tri Isnani ${ }^{3}$, Hari Rudijanto IW $^{4}$ \\ ${ }^{1,2,3}$ Balai Litbang P2B2 Banjarnegara, Jln. Selomanik 16a, Banjarnegara 53415, Indonesia \\ ${ }^{4}$ Poltekkes Kemenkes Semarang. Jln. Tirto Agung Pedalangan, Banyumanik, Semarang 50239, Indonesia \\ *Corresponding Author: Rr. Anggun Paramita Djati, Balai Litbang P2B2 Banjarnegara, Jln. Selomanik \\ 16a, Banjarnegara 53415, Indonesia,Email: anggundjati@gmail.com
}

\begin{abstract}
Background: Various studies have shown that rat density is one of the potential risk factors for leptospirosis events. House conditions can affect the presence of rat that include building materials, construction and also the arrangement in the house.

The Objective: The purpose of this study was to identify the characteristics of houses and socials that were associated with the presence of rats as the basis for rat proof house prototype in endemic and leptospirosis free-village.

Method: This research was a descriptive research with cross sectional design conducted in two regions with leptospirosis endemicity status in Pati Central Java, Indonesia. The study sample was 110 houses in endemic villages and 110 houses in leptospirosis-free villages determined by proportional sampling.

Result: The results showed that the characteristics of the room in the relationship with the existence of rats include wall characteristics, wall conditions, floor conditions, window conditions, irregular house wiring, wall and roof crack. Also, the pile of goods, clothes/cloth, books/paper / cardboard boxes in the house and garbage were strewn around the room.
\end{abstract}

Conclusion: The findings of the study found some characteristics related to the presence and density of rats. A prototype of rodent house has characteristic that is the condition of tight entrance and exit of the house, no hollow, no gap between door frame with a frame or maximum width of gap $0.5 \mathrm{~cm}$.

Keywords: house, rat proof, rat, prototype.

\section{INTRODUCTION}

In Indonesia every year was reported the cases of leptospirosis in humans. In 2010 there were 409 cases of Leptospirosis found in 8 provinces; Jakarta, West Java, Central Java, East Java, Yogyakarta, Bengkulu, Riau Islands, and South Sulawesi. In early 2012, it was reported 828 cases of leptospirosis and 78 of who died (Ditjen PP dan PL Depkes RI, 2010).

Various studies have shown that high density of rats in the settlement is one of the potential risk factors for leptospirosis disease. All living activities of rat are inside the house, covered between kitchen walls, cupboards, warehouses, offices, markets, sewers and others (Ristiyanto, 2007). Home conditions can affect the presence of rats regarding not only building materials and construction but also the arrangement in the house. Home conditions are related to the behavior of house rats in foraging, mating, making nests for their children and their habits (Notoatmodjo, 2003). The house is a building that functions as a residence or occupancy and means of family development. In Indonesia, the housing health requirements referred to in the Decree of the Minister of Health no. 829 The year 1999 about Housing Health Requirements, among others, include residential houses consisting of building materials, components and spatial arrangement of homes, lighting, air quality, ventilation, disease transmitting animals, water, food, waste, and density of sleeping dwellings ( Kemenkes RI, 2009).

Pati regency is one of endemic leptospirosis areas in Central Java Province, Indonesia. According to the Central Java Provincial Health Office data, until April 2014, there were reported 31 cases of leptospirosis in Pati District 
with deaths five people. The number of cases is the second largest number in Central Java Province after Semarang, the capital of the province (Pramestuti, 2014).

Research on the characteristics of rodent or antimouse dwellings and cage in endemic areas of leptospirosis is needed as a basis for making prototypes of rat proof houses that can be applied in socially heterogeneous societies. The purpose of this study was to identify the characteristics of homes and socials associated with the presence of rodents as well as to create a rat proof house prototype design based on specific variables in the presence of rats.

\section{MATERIALS AND METHODS}

This research was a descriptive study with a cross sectional design that was conducted in two regions with different leptospirosis endemicity status in Pati District for 11 months starting from January to November 2016. The sample of the study was 110 houses in the endemic area, and 110 houses in a leptospirosis-free area determined with proportional sampling. Determination of the presence and density of rats based on interview results combined with the number and frequency of rat found from three rat surveys conducted over a period of 1-2 months. Assessment of home characteristics was determined based on interviews and observations. Structured interviews were conducted using previously validated questionnaires while in-depth interviews were conducted using interview guidelines.

\section{RESULT AND DISCUSSION}

\subsection{Result}

Characteristics of respondents in two villages was almost the same. The rat population in two different communities indicated that the density of rats in endemic villages was higher than the nonendemic one. The results showed that the number of houses that had the characteristics of homes easily passed through by rats was more common in endemic villages than in nonendemic areas.

The distribution of the characteristic frequency of homes that are easily passed through by rat in the endemic and leptospirosis-free village is presented in Table 1 .

Table1. Frequency distribution of respondent's home characteristics in the endemic and non endemic villages

\begin{tabular}{|c|c|c|c|c|c|}
\hline Characteristics & $\begin{array}{c}\text { Close house } \\
\text { distance } \\
(n \& \%)\end{array}$ & $\begin{array}{l}\text { Close to yard } \\
\quad(n \& \%)\end{array}$ & $\begin{array}{c}\text { Open Garbage } \\
\text { bin inside house } \\
(n \& \%)\end{array}$ & $\begin{array}{l}\text { Never conducting } \\
\text { rodent control } \\
(n \& \%)\end{array}$ & \\
\hline Endemic & $33(30)$ & $36(34.5)$ & $61(55.5)$ & $47(42.7)$ & \\
\hline Non-Endemic & $56(50.9)$ & $32(29.1)$ & $52(47.3)$ & $38(34.5)$ & \\
\hline Characteristics & $\begin{array}{c}\text { Ventilation easily } \\
\text { passed by } \\
\text { rodents }(n \& \%)\end{array}$ & $\begin{array}{c}\text { Ceiling } \\
\text { partially not } \\
\text { tight }(n \& \%)\end{array}$ & $\begin{array}{c}\text { Floor easily } \\
\text { passed by } \\
\text { rodents }(n \& \%)\end{array}$ & $\begin{array}{l}\text { Entering Door } \\
\quad(n \& \%)\end{array}$ & $\begin{array}{r}\text { Windows } \\
(n \& \%)\end{array}$ \\
\hline Endemic & $77(70)$ & $105(94.5)$ & $37(33.6)$ & $75(68.2)$ & $51(46.4)$ \\
\hline Non-Endemic & $66(60)$ & $102(92.7)$ & $32(29.1)$ & $45(40.9)$ & $42(38.2)$ \\
\hline Characteristics & $\begin{array}{l}\text { Wall partially } \\
\text { permanent } \\
(n \& \%)\end{array}$ & $\begin{array}{l}\text { Wall easily } \\
\text { passed by } \\
\text { rodents } \\
(n \& \%)\end{array}$ & $\begin{array}{c}\text { Wall/roof gap } \\
(n \& \%)\end{array}$ & $\begin{array}{c}\text { Open water duct } \\
(n \& \%)\end{array}$ & $\begin{array}{c}\text { Stick branch } \\
(n \& \%)\end{array}$ \\
\hline Endemic & $39(35.5)$ & $63(57.3)$ & $100(90.9)$ & $102(92.7)$ & $77(70)$ \\
\hline Non-Endemic & $40(36.4)$ & $34(30.9)$ & $64(58.2)$ & $34(30.9)$ & $50(45.5)$ \\
\hline Characteristics & $\begin{array}{l}\text { Goods filing } \\
(n \& \%)\end{array}$ & $\begin{array}{l}\text { Cloth filing } \\
(n \& \%)\end{array}$ & $\begin{array}{c}\text { Book/box filing } \\
(n \& \%)\end{array}$ & $\begin{array}{l}\text { Messy electric } \\
\text { cable }(n \& \%)\end{array}$ & $\begin{array}{l}\text { Garbage } \\
\text { scattered } \\
(n \& \%)\end{array}$ \\
\hline Endemic & $99(90)$ & 79 (71.8) & $77(70)$ & $86(78.2)$ & $42(38.2)$ \\
\hline Non-Endemic & $62(56.4)$ & $53(48.2)$ & $44(63.6)$ & $60(54.5)$ & $40(36.4)$ \\
\hline Characteristics & $\begin{array}{c}\text { Close roof } \\
\text { distance between } \\
\text { houses } \\
(n \& \%)\end{array}$ & $\begin{array}{c}\text { Hanging cable } \\
\text { between } \\
\text { houses } \\
(n \& \%) \\
\end{array}$ & $\begin{array}{c}\text { Open Food } \\
\text { storage } \\
(n \& \%)\end{array}$ & & \\
\hline Endemic & $107(97.3)$ & $99(90)$ & $22(20)$ & & \\
\hline Non-Endemic & $92(83.6)$ & $97(88.2)$ & $31(28.2)$ & & \\
\hline
\end{tabular}

Some of the characteristics of a mouse-infected house are more distributed in endemic areas than in free areas. These features are open dustbins, ventilation, exit door, window, 
wall/ceiling conditions, open or unobstructed drains, tree limbs, piles of goods, clothing, books/papers, messy cables in the house, close spaces between rooftops, and never controlling rat. Characteristics of the house in the form of close inter-house distance (at least three directions of the winds next to the respondent's home is less than equal to one meter), more found at home defendants in the free of the endemic village. As for the characteristics of houses that are quickly passed through by rats between endemic and free communities are not much different in numbers such as the location of the house adjacent to the yard, warehouse, gardens, vacant land, empty house, the nature of walls, wires between homes and open space.

Design or prototype of rat proof house suitable with community condition in the research area in Pati Regency based on the result of this investigation is described in Figure 1.

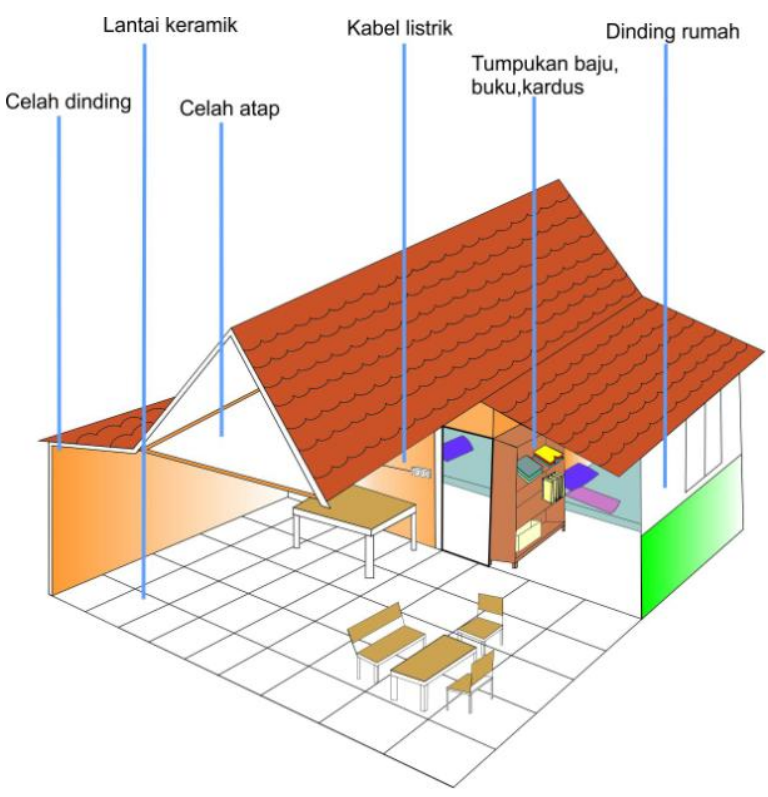

Figure1. Rat proof house design

Notes:

1. Celah dinding $=$ gaps in wall

2. Lantai keramik $=$ ceramics floor

3. Celah atap $=$ holes in rooftops

4. Kabel listrik $=$ electric cable

5. Tumpukan baju, buku, kardus = filing of dress, books, and boxes

6. Dinding rumah $=$ house walls

Design or prototype of rat proof houses suitable with community condition in Pati Regency based on the result of this research is described as follows. Rat proof houses have the characteristics of the state of the tight entrance and exit of the house, no hollow found, no gap between the door frame with the frame, or maximum width of $0.5 \mathrm{~cm}$. Also, the ventilation is not easy for rat to pass through and should be closed tightly using a filter material that is not easily caught or perforated by rats. The condition of the floor should be plastered, as well as the state of the wall of the house. The window opening should be 1 meter above the floor surface below. The window shutters must also be tightened with the frame. Clothes, cloth, books, paper and cardboard and items should be kept neatly in a closed cabinet. Fast food should also be stored in closed cabinets. Once a month the wardrobe for storage of goods and food is checked whether there is a hole or slit of a mouse or not.

\subsection{Discussion}

The results of this study indicate that some characteristics of the house that needs to be considered in particular include the wall, entrance, wall and door gaps, and the arrangement of the house. Wall materials both permanent and non-permanent properties do not show the difference in endemic and nonendemic and neither do not show any association with the presence of rats in the houses.

Each endemic home has the potential of entry of rat due to the condition of the building that is not rat proofing. The presence of a gap at the bottom of the door allows the rat to enter and also the hole around the house used as a garbage dump can become a breeding ground for rats.

The diversity and density of vegetation in leptospirosis endemic areas affect the availability of feed sources and shelter of rat. The arrangement of crop patterns in agricultural areas can minimize the transmission of leptospirosis among farm workers. (Rusmini, 2011). Rats can propagate through branches of trees attached to the roof of the house because the character of a rat is a climbing animal. Rats are rodents that have a variety of physical abilities such as digging, climbing, caving, swimming, jumping, and diving. With so many abilities, rats will find it easier to get food (Barkah Fitriyanto. 2012). The amount of vegetation around the home environment can affect the high population of rodents, as food requirements for rats are met, and rats can grow well.

The presence of a primary reservoir is also a major factor in the transmission of leptospirosis. Intermediate transmission of leptospirosis not 
only by rodents as livestock can also mediate the transmission of leptospirosis. This condition is because the habit of rats who like to live and breed in livestock. Besides, cattle, goats, sheep can be a source of leptospirosis.

Irregular and grungy residential neighborhoods with clustered houses bordering rice fields and gardens are found. The condition of the physical environment of settlements that support the breeding place of rats raises the higher number of rats in the area. Rice fields and gardens are a suitable place for rat which is a type of rodent in making nests, serving as a place for childbirth and raising children; as a place to store food, as a shelter against rain, heat, and predators; as well as a place to rest during the day.

Construction of houses should be made in such a way not to allow rats to hide, to perch and to nest. In a house that has been installed ceiling should be no gap between the roof with the ceiling to prevent entry of rats into the house (Suyono dan Budiman, 2010). These characteristics mentioned above need to be applied in the making of houses by the community. Furthermore, health considerations in building a house are necessary, not only for comfort but also so as not to catch the disease, especially those transmitted by rats. The results of in-depth interviews indicate the absence of health considerations in building homes.

\section{CONCLUSiON}

The number of houses that have the characteristics of quickly passed through rats is more common in endemic villages. As for the attitude and economic aspects in the construction and structuring of houses, in general, there is no difference in these two villages. This evidence can be seen from the views of the distribution of building wall materials in the two villages which are almost similar.

\section{REFERENCES}

[1] Barkah Fitriyanto. 2012. Pemeriksaan Endoparasit Pada Tikus di Balai Litbang P2B2 Banjarnegara. Politeknik Banjarnegara

[2] Ditjen PP dan PL Depkes RI, 2010.

[3] Kemenkes RI. Keputusan Menteri Kesehatan No . 829 Tahun 1999 Tentang: Persyaratan Kesehatan Perumahan.; 1999.

[4] Notoatmodjo S. Pendidikan Dan Perilaku Kesehatan. Jakarta: Rineka Cipta; 2003

[5] Pramestuti N. Laporan Hasil Kegiatan Survei P2B2 Daerah Potensi Kejadian Luar Biasa, Balai Litbang P2B2 Banjarnegara.; 2014.

[6] Ristiyanto. Modul Teknik Survei Tikus.; 2007

[7] Rusmini. 2011. Bahaya Leptospirosis dan Cara Pencegahannya. Yogyakarta. Gosyen Publishing

[8] Suyono dan Budiman. 2010. Ilmu Kesehatan Masyarakat dalam Konteks Kesehatan Lingkungan. Jakarta: EGC.

Citation: Rr. Anggun Paramita Djati, Asyhar Tunissea, Tri Isnani, Hari Rudijanto IW. Modeling Rodent Proof House in Pati Regency to Reduce Leptospirosis. ARC Journal of Public Health and Community Medicine.2017; 2(3):33-36: dx.doi.org/10.20431/ 2456-0596.0203007

Copyright: () 2017 Authors. This is an open-access article distributed under the terms of the Creative Commons Attribution License, which permits unrestricted use, distribution, and reproduction in any medium, provided the original author and source are credited. 